\title{
Marco Díaz Ruiz (1942-1997)
}

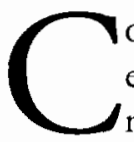

Tомо тоDos los fenómenos determinantes en la existencia humana y en la naturaleza, la muerte es una e infinitas muertes a la vez. Cada muerte es totalidad irreversible y singularidad de lo único e irrepetible, desde una célula hasta un árbol. Mas con el privilegio y condena de la conciencia, con su poderío no sólo sobre las ideas, también en las emociones y el instinto, nuestra vivencia de la muerte, y de la muerte humana, es de una hosquedad trágica. La vivimos como representación de un "fin último" inevitable (somos parte de la naturaleza), ligada a los afectos de toda estirpe: el amor y el odio, el acogimiento y el rechazo, la simpatía y la antipatía, estados del ser ante los que la conciencia puede jugar el papel de dominio objetivo o de súbdita que naufraga en la fuerza de las intensidades que la sobrepasan y arrastran.

Cuando alguien cercano muere, estamos en un "no creerlo" y en una especie de reacomodo interno más o menos difícil, según la jerarquía afectiva que tenía en nuestra vida el ser que partió.

El fallecimiento de un colega y amigo provoca extrañeza y dolor inmediatos, pero también marca el inicio de la ausencia de alguien que, más cerca o más lejanamente, hacía lo mismo que nosotros, contribuyendo al acervo de reflexión y erudición de las materias que nos ocupan, y al ir y venir del intercambio cotidiano de vivir, apoyarse, criticarse positiva o negativamente en los espacios de la institución de trabajo, o fuera, en un café, en la sala de una casa o en el parque.

Marco Díaz Ruiz, maestro en historia del arte por la Facultad de Filosofía 
y Letras de la UNAM y miembro del Instituto de Investigaciones Estéticas de la misma universidad desde los años setenta, murió en julio de 1997, a los cincuenta y cinco años de edad. Su muerte súbita causó consternación; desde hacía varios años lo acosaba una enfermedad nerviosa, que alteró sobre todo su capacidad motriz y agudizó extremosamente su sensibilidad, hasta un estado angustioso que se hizo crónico en su sentimiento y concepción del mundo, la vida, la amistad, el trabajo y el ambiente académico.

Marco era un hombre reflexivo, muy sensible e irónico, de vasta cultura, conocedor de su materia principal, la arquitectura colonial, y poseedor de un excelente manejo del español, a veces un poco rígido en su exigencia de hablarlo con precisión constructiva y elegancia y vuelo en sus figuras. Fue investigador y secretario académico del instituto y profesor en la Facultad de Filosofía y Letras.

Valorar la estructura y las formas arquitectónicas sin ligarlas fundamentalmente con aspectos sociales era uno de los centros de su análisis. Así, en su gran libro, quizá el más significativo de su producción, La arquitectura jesuita del siglo XVIII, hace toda una caracterización de lo que es una obra arquitectónica jesuita, pues en la historiografía de la producción artística colonial habita el problema de si existe o no una arquitectura de cada orden (agustinos, franciscanos, dominicos). Marco sustenta, además, la tesis de que el arte jesuita es el arte de la contrarreforma, concepción heredada de Weisbach, clásico estudioso del barroco. Para concretar sus conceptos, tomó como paradigmas las iglesias de la Compañía de Jesús en Tepotzotlán, Puebla y Guanajuato.

También se le debe un estudio de los conjuntos conventuales de Atlixco, hasta la fecha única investigación global sobre esa arquitectura. La edición fue ilustrada con excelentes fotografías, aspecto en el que Marco era sumamente cuidadoso. Su postura y criterio abiertos a las manifestaciones del arte en general (también incursionó en el arte del siglo xx en conferencias y cursos) le permitieron derivar al mundo del neoclásico, especialmente en el caso de la ciudad de León, giro nada extraño ya que él conocía con firmeza el arte antiguo grecorromano. En tiempos cercanos a su muerte, este investigador estaba trabajando en una reedición de su trabajo sobre Atlixco y dando los últimos toques a un ensayo sobre la arquitectura de Lagos de Moreno.

Desde que la afección psíquica comenzó a asolarlo, Marco vivió una batalla campal por recuperar su ritmo de trabajo y dar un nuevo cauce a su vida en general. Se le veía ir y venir por los pasillos del instituto, buscando a 
DOI: http://dx.doi.org/10.22201/iie.18703062e.1997.71.1791

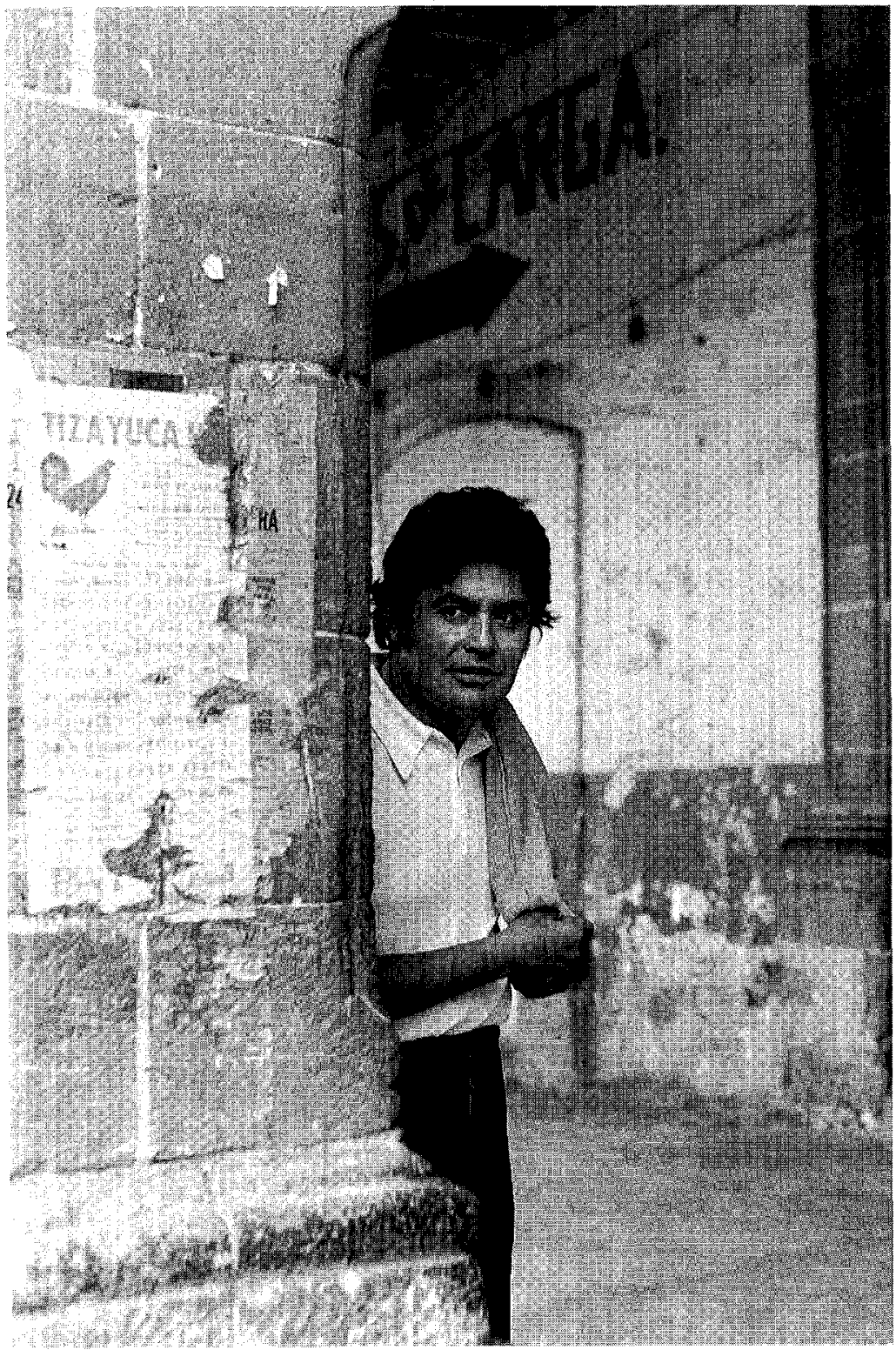

Marco Díaz en Ixmiquilpan, Hidalgo, en julio de 1976.

Foto: Amada Martínez Reyes, Archivo Fotográfico IIE-UNAM. 
los muchachos de intendencia, a Leticia López Orozco o a mí. Fuimos testigos de sus esfuerzos por volver a trabajar en su cubículo y, sobre todo, por leer, actividad que pudo llevar a cabo siempre, con lucidez, hasta su fin.

Como la de todo amigo o companero de trabajo, la muerte de Marco Díaz duele. Ojalá que en nosotros, como colegas —o en mí, como su amiga-, logre levantarse sin reservas, y perdurar, la imagen del muy buen investigador que fue durante sus mejores años, y la del compañero de los cálidos "detalles" (chocolates, galletas, saludos en papelitos o alguna revista de estérica o de historia del arte sobre mi escritorio al llegar en la mañana al instituto). Marco estaba construido de la ambigua materia de luz y sombras, conflictos y contradicciones, adolescencia y madurez, agudeza y desacierto, a lo cual no hay ser humano que escape. $\$$ 